\title{
Preparation of Speciality-Integrated Assignments in Informatics Study Courses at the Higher Education Level
}

\author{
Māris VĪTIN̦Š́n ${ }^{1}$, Oskars RASNAČS ${ }^{2}$ \\ ${ }^{1}$ University of Latvia \\ 19 Raina blvd., Riga, LV1586, Latvia \\ ${ }^{2}$ Rìga Stradinš University \\ 16 Dzirciema str., Riga, LV 1007, Latvia \\ e-mail:maris.vitins@lu.lv,rz15r01@inbox.lv
}

Received: September 2011

\begin{abstract}
Information and communications technologies today are used in virtually any university course when students prepare their papers. ICT is also needed after people are graduated from university and enter the job market. This author is an instructor in the field of informatics related to health care and social sciences at the Rīga Stradinšs University. In practice, he has found that after completing informatics courses (IC) at the university level, students and practicing specialists at various levels find it hard to decide on what data processing method to use in order to interpret extracted results in the relevant area of specialisation. There are various data processing methods in the literature, presented individually and without adequate linkages. The author has found in practice that when such assignments are handled, there is closer linkage among data processing methods than the literature would suggest.

In this article, the authors deal with the following issues:

(1) how assignments given during informatics courses at the university level can be integrated with the relevant area of specialisation by making use of professional standards, guidebooks to studies in other courses, descriptions and scholarly publications so as to help students and practicing specialists to take decisions on data processing methods, their use, and the interpretation of their results;

(2) how to ensure that educational data related to the area of specialisation are obtained on the basis of statistics in scholarly publications;

(3) what kind of content is to be used for students of health care and the social sciences;

(4) how to choose methods to resolve data processing issues;

(5) what are the recommended principles for evaluating the knowledge, skills and talents of students?

The views that are presented in this paper are those of the authors or of other authors.
\end{abstract}

Keywords: tests, informatics, integration.

\section{Introduction}

Research conducted by the author at the Rīga Stradinš̌ University shows that many students and practicing specialists require consultations in relation to the selection, use and 
interpretation of data processing methods when writing research papers. In providing such consultations, the author has encountered the following problems:

- a lack of knowledge and understanding about concepts and data processing methods;

- an inability to define linkages among concepts and data processing methods;

- an inability to read the flow charts of algorithms;

- difficulty in understanding the information and communications technology (ICT) and statistical concepts which are in algorithms, as well as the relevant data processing methods and their relationship to the concepts;

- difficulty in selecting one of the normal distribution criteria that are available;

- diverse understandings of qualitative and quantitative data and measuring scales; in psychology and art therapy, for instance, round scale data (different assessments in scores) are seen as quantitative data (Martinsone et al., 2009).

The following things have been done in the world to deal with these problems:

- the content of information courses is designed and implemented at any university where health care and social science courses are offered;

- there are ECDL requirements related to the use of ICT in everyday life and in various processions;

- there are textbooks on the use of statistics in health care and the social sciences, complete with relevant examples;

- there are various algorithms in the form of flow charts and summarising tables (Table 1) in line with the statistical method that has been chosen (Teibe, 2001, 2007).

Table 1

Classification of data processing assignments and the selection of solutions on the basis of the distribution

\begin{tabular}{lll}
\hline Tasks & $\begin{array}{l}\text { Quantitative normal } \\
\text { distributed data }\end{array}$ & Non-parametrics (all other cases) \\
\hline $\begin{array}{l}\text { Descriptive statistics } \\
\begin{array}{l}\text { Two independent group } \\
\text { comparison by one variable }\end{array}\end{array}$ & Mean, std. deviation & Median, mode, inter-quartile range \\
$\begin{array}{l}\text { Two dependent group comparison } \\
\text { by one variable }\end{array}$ & Paired sample, sample t test & Wilcoxon, sign and McNemar criterion \\
$\begin{array}{l}\text { Three and more independent group } \\
\text { comparison by one variable }\end{array}$ & ANOVA & $\begin{array}{l}\text { Mann-Whitney, Kolmogorov-Smirnov, } \\
\text { Wald-Wolfowitz, chi-square and Fisher }\end{array}$ \\
$\begin{array}{l}\text { Three and more dependent group } \\
\text { comparison by one variable }\end{array}$ & Fridman ANOVA & $\begin{array}{l}\text { Kruskal-Wallis, median and chi-square } \\
\text { criterions }\end{array}$ \\
$\begin{array}{l}\text { Two variable relationship analysis } \\
\text { Three and more variable coinci- } \\
\text { dent analysis }\end{array}$ & $\begin{array}{l}\text { Pearson correlation analysis } \\
\text { factor and cluster analysis }\end{array}$ & $\begin{array}{l}\text { Fridman ANOVA, Cochran criterion } \\
\text { Chi-square criterion, Spearman, Kendall } \\
\text { and gamma correlation analysis }\end{array}$ \\
\hline
\end{tabular}


The authors believe that the following factors create problems here:

- There has been no identification of the minimal knowledge skills and talents that are needed to write research papers at various study levels;

- professional standards, study guidelines and statistics from scholarly literature are not used to a sufficient extent;

- testing assignments are not in line with the decisions that are necessary to write a research paper;

- the Table 1 and the flowcharts of algorithms do not state which of the many normal distribution criteria should be used.

Normal distribution criteria, to a certain extent, can be divided into qualitative criteria (the Lyapunov theory, construction of a histogram) and quantitative criteria (the Kolmogorov-Smirnov test). The qualitative criteria make it possible to assume that any quantitative data are distributed normally. In that case, it turns out that more than one method can be used to address one and the same situation. The same is not indicated in the flowcharts (Teibe, 2001, 2007).

It is of importance to great interest among students at various levels and to convince them that ICT skills will be of use to them in their area of specialisation, offering appropriate examples in this process. It is for this purpose that there are teaching resources and scholarly articles which address such examples - new and ever new ones, moreover. It is important to make skilful use of data from such publications in the teaching process.

\section{The Concept of Integration}

In a dictionary of pedagogic terminology, we read that integration is a process in which individual elements, sub-systems and sections are brought together into a single systemic whole (a system). In the process of education, this relates to subject matter, resolution of problems, learning and research, bringing all of these into a single whole in terms of the knowledge and skills that are to be learned and achieved during a specific course of study. This can be done through specifically integrated study courses, or via an integrated review of the components of a single topic of study (Skujiņa, 2000).

For informatics courses at the higher education level, there are two important types of integration, as described by the American pedagogy specialist Robin Fogarty; cited in Andersone (2007):

- the fragmentary type of integration, in which students take individual and clearly separate study courses which are internally integrated in terms of content, but are not linked among themselves;

- the linked type of integration, in which subject matter in the various courses of study is linked so that a unified understand emerges vis-a-vis the fundamental concepts in the process.

The authors believe that the linked type of integration is better for students.

The utility of integration has been studied by numerous scholars. Lipson has described the positive effects of integration; cited in Andersone (2007): 
- an integrated programme helps students to develop their skills;

- an integrated set of basic knowledge allows students to learn information quickly;

- diverse perspectives lead to a broader base of integrated knowledge;

- an integrated programme encourages more in-depth and more expansive learning;

- an integrated programme encourages positive attitudes among students vis-a-vis their learning;

- an integrated programme allows time for research.

The authors believe that these claims can be reformulated specifically for universitylevel informatics courses:

- students can produce high-quality research papers;

- ICT studies can be put to professional use and practice;

- students can learn in accordance with the latest trends and developments in the field of computer science.

The author's experience is that if an assignment is formulated and techniques for solving the problem are based on several single-use or multi-muse modules, then it is possible to learn the information more quickly than is the case with teaching about each usage in turn.

The fact is that the writing of research papers for virtually any course of study at the university level will involve the use of IT. For that reason, the authors feel that the best option is to ensure that within informatics courses, theoretical knowledge from the field of ICT and other areas is brought together into a single whole - something that is discussed in professional standards, study guidebooks and scholarly publications.

\section{Documents Related to the Information which Specialists Need}

In any sector, the information which specialists must receive is identified in documents such as study guidebooks (e.g., the study guidebook of the Rìga Stradiņš University, 2011), course descriptions (The University of Latvia Information System Course Register, 2011), professional standards (The Register of Professional Standards, 2011), and scholarly publications in the sector (scholarly papers from the Rịga Stradinš̌ University, 2008; theses from the Rīga Stradiņš University, 2009; theses from the Rīga Stradinš̌ University, 2010; theses from the Rīga Stradinš̌ University, 2001). It was on the basis of this fact that the authors defined a new criterion for the integration of computer studies and studies in other areas of specialisation: Integration between computer studies and other studies occurs if issues related to the informatics course is linked to study guidebooks, course descriptions, professional standards and scholarly publications in the relevant sectors.

Professional standards, study guidebooks and course descriptions usually go into greater or lesser detail as to subject matter which students must learn. Scholarly publications speak to subjects related to professional standards and other sources of information in relation to specific topics in each sector, as well as innovations in the publications themselves (Fig. 1). The content of courses, as described in course descriptions and study 


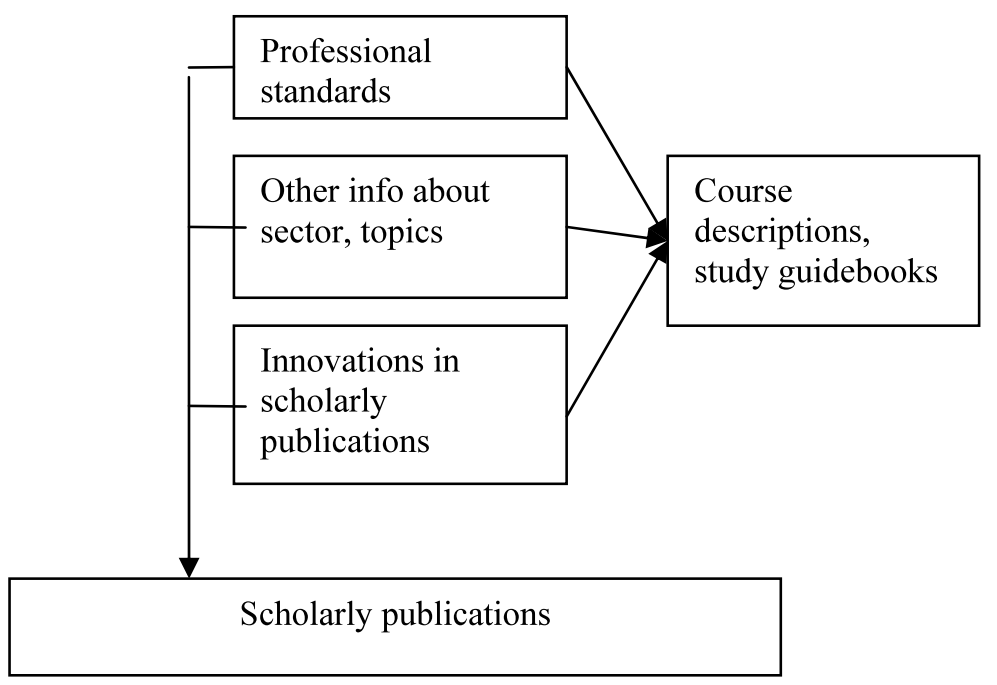

Fig. 1. The relationship among professional standards, study guidebooks, and scholarly publications in the sector.

guidebooks, is in turn based on professional standards, other sources of information about topics in the relevant area of specialisation, and innovations presented by the authors of scholarly publications.

Specialists in one area usually need to study issues related to many other sectors, particularly those which are closest to the subject matter at hand. Public health specialists, for instance, must learn a great deal about medicine and other aspects of the health care system. This represents a very complicated structure in terms of linkages among the various sectors, and this is very difficult to depict on a grid. If we look at the study guidebooks and professional standards of the RSU and other institutions of higher learning, however, we see that in all cases, students pursuing careers in health care or the social sciences must deal with issues that various sectors have in common.

Specialisations related to health care and the social sciences represent an integration of computer science, mathematics, statistics, business, pedagogy, legislation, contact psychology, etc. The authors have prepared a grid to depict the way in which computer studies are integrated into other sectors (Fig. 2).

All sectors are integrated with computer studies and business. The labour market and industry - those are business issues which are, therefore, linked to any other sector. Each company needs sector-specific bookkeeping and financial services, and it may well encounter issues related to planning of manufacturing, lending obligations, savings, supply and demand, profits, costs and expenditure of resources (Frolova, 1999; VedI̧a, 2000).

It is also true that people in virtually any sector of the economy must work with clients. This requires contact psychology skills (Interactive Encyclopaedia of Psychology, 2011).

All sectors are integrated with computer science and pedagogy. Each sector needs the training of new specialists and the enhancement of the qualifications of existing ones. 


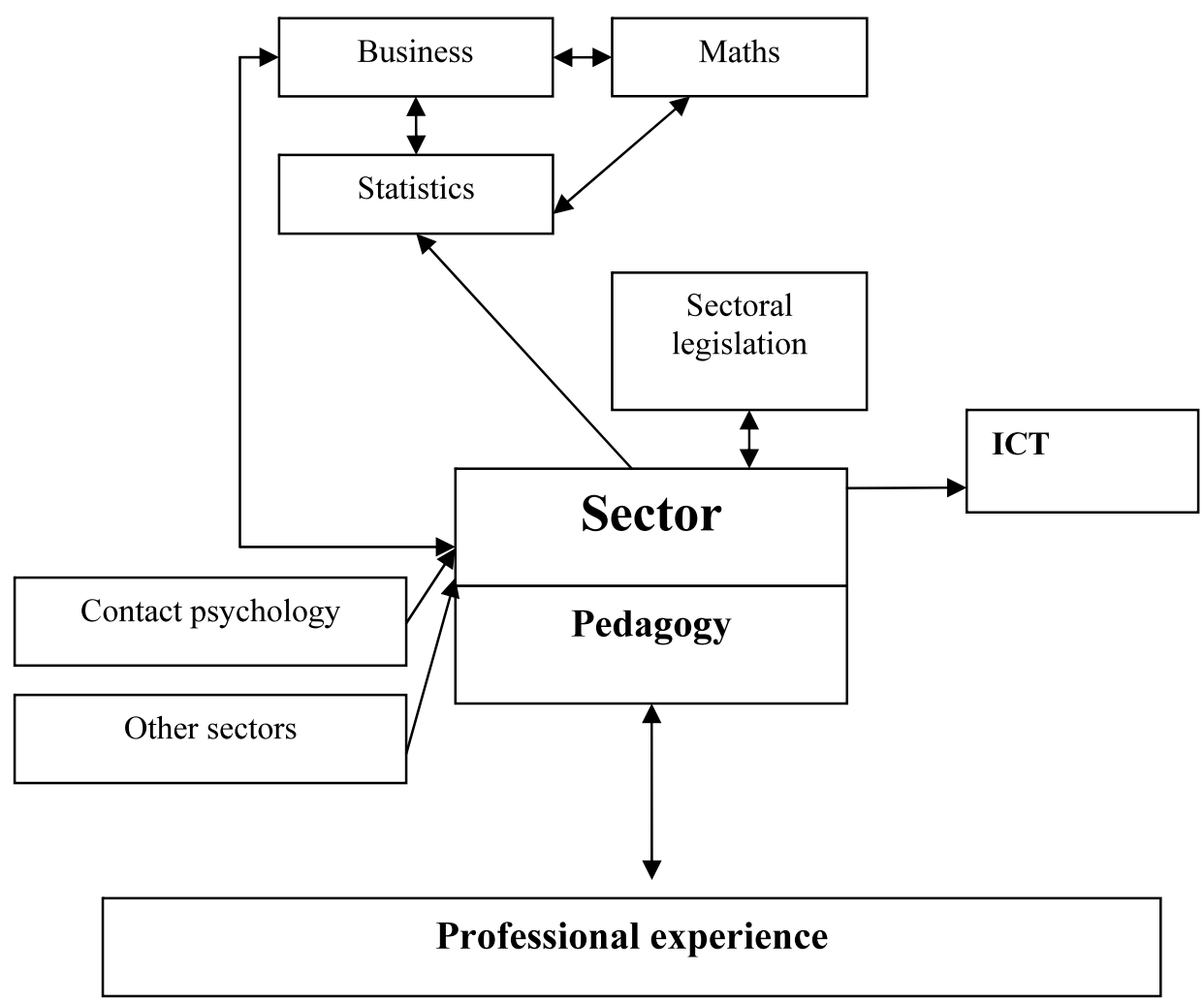

Fig. 2. Integration of computer science with other sectors.

All sectors are integrated with computer science and relevant legislation. This is true in two respects. First of all, there are several laws which relate both to computer science and other sectors - the law on statistics (2009), the law to protect the personal data of individuals (2010), and the law on information transparency (2010). It is also true that laws and legal norms are published on many Internet homepages. Each sector has its own specific laws and legal norms. In the health care industry, these are the law on medicine (2011), the law on patient rights (2009), etc.

Figure 2 allows us to conclude that the best way to offer informatics courses at the higher education level is to find examples for the sector itself. Also to be supported, however, are examples from the fields such as contact psychology, sectoral legislation, and other related sectors (as indicated in professional standards and study guidebooks).

In practice, this is how the author has found that linked information is transformed: $x \rightarrow f(x)$ or $x \rightarrow f(x) \rightarrow g(x)$, where $x$ relates to information related to the area of specialisation that is entered into the computer, $f(x)$ relates to information transformed by any method that is linked to the area of specialisation, and $g(x)$ relates to the interpretation of the information that has been transformed by the software.

In order to prepare assignments for students which have to do with text processing and presentations, it is necessary to tell students about the relevant set of words and concepts 
in the area of specialisation, as based o professional standards, study guidebooks, course descriptions and scholarly publications. An example would be the need to determine blood cholesterol levels in a course related to health care. Students must learn how to find information on the Internet and to transform it via text processing or presentations.

\subsection{The First Stage of the Research}

Before and during the research, the authors looked for new applications of ICT in the areas of health care and the social sciences, and several scholarly publications were produced during this time. These results can be used for informatics courses at the university level (Grūtupa et al., 2009; Zakrizevska et al., 2009).

In order to address this issue, the authors did the following things during the second semester of the 2009/2010 academic year:

- adjusted the content of learning;

- adjusted the algorithm for selecting data processing methods (Table 1);

- expanded the range of educational data as generated from scholarly publications;

- taught sets of concepts in English related to techniques that can be brought to bear when dealing with assignments at a university-level informatics course (e.g., Independent Sample t-test).

In consultation with colleagues from other universities, we prepared educational content at three levels - minimal, in-depth and optimal.

The minimal level speaks to the knowledge, skills and talents that are needed to write research papers at the college level. Sometimes this is enough to write a bachelor's thesis, but in most cases that is not true.

- information and communications, basic text processing;

- types of surveys and extraction of data;

- basic data processing via the use of electronic tables or statistical software;

- entry and interpretation of results in text processing software;

- final text processing with in-depth ECDL questions;

- presentation.

The optimal level speaks to the knowledge, skills and talents that are needed to write a bachelor's or master's thesis:

- working with the names and personal codes of individuals;

- sample and population (general population);

- elements of the theory of probability;

- all areas of specialisation in which measuring instruments are important - processing of the results of measurements;

- normal distributions and criteria to inspect them;

- in-depth descriptive statistics;

- comparing one cohort to the population;

- comparing two independent groups on the basis of one variable;

- comparing two dependent groups on the basis of one variable;

- comparing three or more independent groups; 
- comparing three or more dependent groups on the basis of one variable;

- simultaneous analysis of three or more variables.

The in-depth level refers to additional knowledge, skills and talents apart from those listed above. The author believes that the following things can be learned in all areas of health care and the social sciences:

- merges of mail;

- macro-commands;

- programming languages;

- database software;

- image processing software;

- economic issues addressed with the help of ICT;

- bookkeeping software;

- MathCad (or software such as QuickMath);

- mathematic modelling.

Other ICT-related issues which are of importance in the relevant area of specialisation:

- in the area of medicine and public health, there is the issue of analysing dynamics (time) and life expectancy;

- in the area of orthotics and prosthetics, there are CAD systems which are useful for drawing (TurboCad, AutoCad);

- in the areas of art therapy and psychology, there is application software that is useful for recording sessions, as well as sound and video editing software;

- for various medical specialists, there is work involving digital medical equipment;

- there are GIS systems for emergency response staff;

- there is bionic modelling software for specialists in medical physics;

- there are other options, as well.

The author believes that successful integration in the educational process should be based on data tables that are based on the actual work of specialists. The problem is that Latvia's law on statistics (2009) states that statistical information may not be published or otherwise disclosed in a way which directly or indirectly makes it possible to identify an individual or a legal entity. An example relates to data in the health care sector which relates to a specific patient or client. The more data columns or elements, the greater the possibility that a patient could be identified indirectly even if the patient's name, surname, personal code and address are not indicated. There is also the problem that the law on protecting the data of individuals (2010) states that data cannot be disclosed without the permission of patients/clients. How to resolve this issue so that students can work with data which are close to the true data of the area of specialisation?

The authors would propose the generation of data in the MS Excel environment on the basis of statistical indicators shown in scholarly publications. The authors have conducted research to show that publications written by health care and social sciences specialists mostly offer the following statistical indicators - mean and standard deviation (the confidence interval) or the relative frequency $(\%)$.

In order to come up with assignments which are integrated with the area of specialisation in the area of data processing, the following processes are necessary: 
- find the relevant set of words in scholarly publications about the area of specialisation and the relevant statistical indicators - the average arithmetic and standard deviation or relative frequencies $(\%)$;

- find the necessary type of assignment;

- adjust the relevant statistical indicators in accordance with the type of assignment;

- generate the relevant data via MS Excel or generators of random numbers from the Internet.

Each solution is in line with a characteristic set of words. In practice, the authors have found that it is important for students to learn the relevant word sets in English (Table 2) irrespective of the language of the education process. Then the necessary information must be found on the Internet or in the literature in a comparatively brief period of time.

The authors adjusted the algorithm used in selecting data processing methods. On the basis of the recommendations shown in Table 1, the authors have offered the scheme that is in Table 2 - one which relates to different normal distribution criteria and recommendations from specialists, with the following comments:

- students can add data from the round scale to quantitative and qualitative data as they see fit;

- students can use any normal distribution criterion that they wish to use.

Table 1 did not mention the situations "One sample comparison with the population," "Graphs," and several important descriptive statistical indicators. For that reason, the authors have supplemented Table 2 with new elements. The research papers of students were evaluated on the basis of this scheme.

The authors proposed the following criteria to evaluate the effectiveness of the work that was done:

- the average test results of students - selection of solution techniques in accordance with the algorithm (Prokofjeva, 2007; Jevsjukova, 2009);

- an evaluation of the extent to which tests given to bachelor's degree students, specialists with a higher education and faculty members are in line with the area of specialisation;

- an evaluation of the difficulty of tests given to specialists with a higher education and to faculty members;

- an evaluation of the extent to which courses taken by bachelor's degree students, specialists with a higher education, and faculty members are in line with the area of specialisation.

The authors asked experts about the level of difficulty of these kinds of tests (on a fivepoint scale, with 1 being the easiest test and 5 being the most difficult one). We also asked them about the extent to which the tests were appropriate for university-level informatics courses and the relevant area of specialisation (again a five-point scale, with 1 being the least appropriate and 5 being the most appropriate).

The experts were divided into three groups - bachelor's degree students, specialists with a completed higher education, and faculty members. We took into account the areas of specialisation in which faculty members teach informatics courses. One instructor can teach informatics courses in several areas of specialisation, and the evaluation of tests 
Table 2

Word sets characteristic of the solution techniques proposed by the authors

\begin{tabular}{|c|c|c|}
\hline Type of task & Quantitative data & Qualitative data \\
\hline Descriptive statistics & $\begin{array}{l}\text { Mean, median, mode, quartiles, per- } \\
\text { centiles, minimum, maximum, range, } \\
\text { variance, std. deviation, inter-quartile } \\
\text { range, std. error of skewness, std. er- } \\
\text { ror of kurtosis; frequencies, relative fre- } \\
\text { quencies, dividing into classes }\end{array}$ & $\begin{array}{l}\text { Median, mode, quartiles, percentiles, } \\
\text { minimum, maximum, range, inter- } \\
\text { quartile range; frequencies, relative } \\
\text { frequencies for separate values }\end{array}$ \\
\hline Graphs & $\begin{array}{l}\text { Histogram frequency polygon, distribu- } \\
\text { tion line }\end{array}$ & Column bar, pie charts \\
\hline $\begin{array}{l}\text { One sample comparison } \\
\text { with population }\end{array}$ & $\begin{array}{l}\text { Confidence intervals of means, one sam- } \\
\text { ple Student t-test, chi-square test }\end{array}$ & $\begin{array}{l}\text { Proportion confidence intervals, chi- } \\
\text { square test }\end{array}$ \\
\hline $\begin{array}{l}\text { Two independent group } \\
\text { comparison by one vari- } \\
\text { able }\end{array}$ & $\begin{array}{l}\text { Independent sample Student t-test, } \\
\text { Mann-Whitney, Kolmogorov-Smirnov } \\
\text { tests }\end{array}$ & $\begin{array}{l}\text { Mann-Whitney, Kolmogorov-Smir- } \\
\text { nov, chi-square tests }\end{array}$ \\
\hline $\begin{array}{l}\text { Two dependent group } \\
\text { comparison by one vari- } \\
\text { able }\end{array}$ & $\begin{array}{l}\text { Paired sample Student t-test, Wilcoxon, } \\
\text { sign tests }\end{array}$ & Wilcoxon, sign, McNemar tests \\
\hline $\begin{array}{l}\text { Three and more indepen- } \\
\text { dent group comparison } \\
\text { by one variable }\end{array}$ & $\begin{array}{l}\text { Analysis of variance (ANOVA), } \\
\text { Kruskal-Wallis, median tests }\end{array}$ & Wilcoxon, sign, McNemar tests \\
\hline $\begin{array}{l}\text { Three and more depen- } \\
\text { dent group comparison } \\
\text { by one variable }\end{array}$ & Friedman, Kendall tests & $\begin{array}{l}\text { Kruskal-Wallis, median, chi-square } \\
\text { tests }\end{array}$ \\
\hline $\begin{array}{l}\text { Two variable relation- } \\
\text { ship analysis }\end{array}$ & $\begin{array}{l}\text { Pearson, Spearman, Kendall, gamma } \\
\text { correlation analysis, regression analysis }\end{array}$ & $\begin{array}{l}\text { Spearman, Kendall, gamma correla- } \\
\text { tion analysis, chi-square tests }\end{array}$ \\
\hline $\begin{array}{l}\text { Three and more variable } \\
\text { coincident analysis }\end{array}$ & $\begin{array}{l}\text { Multiple linear regression analysis, } k \text { - } \\
\text { mean cluster analysis }\end{array}$ & Cronbach alfa analysis \\
\hline
\end{tabular}

given in the various areas of specialisation can be different. We surveyed 234 bachelor's degree students (with respect to all types of tests and independent projects), 26 specialists with a higher education (including residents, master's degree students and doctor degree students in areas of health care specialisation), and 37 instructors from the areas of specialisation in which they teach classes. Some of the interviewees did not have an opinion about some of the questions that were posed to them.

In order to evaluate the results of the work that was done by the students, the authors came up with a test with questions to which several correct answers were possible. For instance, which method do you recommend for comparing blood cholesterol levels by gender?

- the independent sample Student t-test;

- the Mann-Whitney test;

- the Komogorov-Smirnov tests;

- ANOVA; 
- the Friedman test;

- neither of the variants.

The test was used to test the ability of students $(n=93)$ to take the correct decisions vis-a-vis the preferred solution technique and to do so quickly. The test was also given to faculty members $(n=9)$ and students from other institutions of higher education.

One of the problems in this is that the test with elective responses does not sufficiently examine the depth of knowledge (Prokofjeva, 2007; Jevsjukova, 2009). In adding data files to the questions on the tests, the authors tried to ensure that the decision was more considered. Independent projects in which data processing assignments have to be resolved with the help of ICT are better at testing the depth of knowledge, but it takes a long time to grade them. A convenient option for answers on tests is similar to answers on questionnaires.

There are various computerised systems to put together computerised tests (QuizEgg, 2011; the software package "Tests", 2002) which make it far easier for faculty members to do their work. The authors also believe, however, that there are substantial shortcomings to this software:

- incoming data are not compatible with the MS Excel environment which offers various opportunities for automation, which means that the instructor must do a great deal of work in preparing tests;

- results related to each assignment do not appear on the overall data table;

- there is a lack of training functions with briefly described materials that could be useful for repetition.

For that reason, the authors helped in designing testing software so as to address the stated shortcomings (Rasnačs and Vītiņš 2011).

The results of tests taken by faculty members show that the issue of correct answers to questions related to data processing are not unambiguous. They could select different solution techniques for the same assignments. That is because faculty members have different views about small cohorts, qualitative and quantitative data, measuring scales, and criteria to test the correspondence of normal distributions. The experience of the authors shows that when appropriate solution techniques are discussed, there are different viewpoints. The suggestion of the authors is that each faculty member prepare his or her own scheme of correct answers to questions about data processing.

Table 3 shows the results of the first segment of the research.

The results of student work were poor (an average of 3 points according to the study rules of the RSU). Faculty members, by comparison, thought highly of the appropriateness of the tests. The extent to which study courses were appropriate for the area of specialisation was rated quite highly, but several problems emerged when analysing the course content:

- some methods from the subject "Three and more variable coincident analysis" are mathematically complicated and cannot often be put to practice;

- students lacked skills in working with MS Excel.

For that reason, the content of teaching was adjusted in partnership with experts. 
Table 3

The results of the first segment of the research

\begin{tabular}{|c|c|c|}
\hline Names of evaluations & Evaluations & $n$ \\
\hline $\begin{array}{l}\text { The average results of students in tests - the selection of solution techniques in ac- } \\
\text { cordance with the algorithm }\end{array}$ & $48.68 \%$ & 93 \\
\hline $\begin{array}{l}\text { The average evaluation of bachelor's degree students in terms of the appropriateness } \\
\text { of tests in relation to the area of specialisation (5-point scale) }\end{array}$ & 3.6 & 44 \\
\hline $\begin{array}{l}\text { The average evaluation of specialists with a higher education in terms of the appro- } \\
\text { priateness of tests in relation to the area of specialisation (5-point scale) }\end{array}$ & 3.4 & 7 \\
\hline $\begin{array}{l}\text { The average evaluation of faculty members in terms of the appropriateness of tests in } \\
\text { relation to the area of specialisation (5-point scale) }\end{array}$ & 4.4 & 20 \\
\hline $\begin{array}{l}\text { The average evaluation of specialists with a higher education with respect to the dif- } \\
\text { ficultness of the test (5-point scale) }\end{array}$ & 4.3 & 6 \\
\hline $\begin{array}{l}\text { The average evaluation of faculty members with respect to the difficultness of the test } \\
\text { (5-point scale) }\end{array}$ & 5.0 & 12 \\
\hline $\begin{array}{l}\text { The average evaluation of bachelor's degree students in terms of the appropriateness } \\
\text { of the study course ( } 5 \text {-point scale) }\end{array}$ & 3.6 & 93 \\
\hline $\begin{array}{l}\text { The average evaluation of specialists with a higher education in terms of the appro- } \\
\text { priateness of the study course (5-point scale) }\end{array}$ & 4.1 & 7 \\
\hline $\begin{array}{l}\text { The average evaluation of faculty members in terms of the appropriateness of the } \\
\text { study course (5-point scale) }\end{array}$ & 3.6 & 20 \\
\hline
\end{tabular}

\subsection{The Second Segment of the Research}

The second segment of the research was conducted during the first half of the first semester in the 2010/11 academic year. The following content was offered to students:

1. The minimal level

1.1. Data entry in MS Excel

1.2. Seeking information on the Internet about the area of specialisation

1.3. Basic elements of MS Word for research papers

1.4. In-depth elements of MS Word for research papers

1.5. MS PowerPoint presentations

1.6. Series of data in MS Excel

1.7. Activities in MS Excel

1.8. The automatic filter and data structuring of MS Excel - different conditions

1.9. Special pasting in MS Excel

1.10. Data extraction

1.11. Calculating the main descriptive statistical indicators in MS Excel

1.12. Calculating frequencies and depicting them graphically in MS Excel

2. In-depth descriptive statistics and work with the SPSS application

2.1. Entering data in SPSS, exchange of data between MS Excel and SPSS 
2.2. SPSS activities important for research papers

2.3. Calculation of statistical indicators

2.4. Calculating frequencies and depicting them graphically in SPS

3. Additional aspects of MS Office applications

3.1. Important MS Excel calculations for research papers

3.2. Protecting MS Office files and pages with a password

3.3. Macro-commands for MS Office applications

3.4. MS Access tables

3.5. MS Access forms

3.6. MS Access reports

3.7. MS Access requests

3.8. Additional elements of MS Access

4. Fundamental elements of testing hypotheses and researching relationships

4.1. Elements of the theory of probability

4.2. Data distribution

4.3. Testing of hypotheses

4.4. Graphs between two variables - combinations of different distributions and measuring scales

4.5. Comparison of one cohort with the population

4.6. Comparison of two independent groups on the basis of one variable

4.7. Comparison of two dependent groups on the basis of one variable

4.8. Comparison of three or more independent groups

4.9. Comparison of three or more dependent groups on the basis of one variable

4.10. Analysis of linkages between two variables

4.11. Fundamental aspects of three and more variable coincident analysis

5. Additional elements of testing hypotheses and relationships

5.1. Additional elements in simultaneous analysis of three or more variables

5.2. Analysis of time series

5.3. Linearization

5.4. Survival analysis

5.5. Work with syntaxes in the SPSS application

5.6. Other statistical applications such as the freeware EPIINFO application

6. Other elements in research related to data processing and publication of results ones that are of importance in the specific area of specialisation

7. Knowledge, skills and talents that are important in the labour market

This educational content addressed the issue of which methods from the "Three and more variable coincident analysis" should be learned during bachelor's, master's and doctoral studies. The methods were divided into basic elements (multiple linear regressing, $k$-analysis of average clusters) and supplementary issues (general linear model, logistic regression). Each course also included repetition of learning about MS Excel.

Students were given test questions with six possible answers. The final was "None of the options." Several correct answers were offered, but students had to choose the one which they thought was most appropriate. 
Table 4

The results of the second segment of the research

\begin{tabular}{|c|c|c|}
\hline Names of evaluations & Evaluations & $n$ \\
\hline $\begin{array}{l}\text { The average results of students in tests - the selection of solution techniques in ac- } \\
\text { cordance with the algorithm }\end{array}$ & $64.47 \%$ & 30 \\
\hline $\begin{array}{l}\text { The average evaluation of bachelor's degree students in terms of the appropriateness } \\
\text { of tests in relation to the area of specialisation (5-point scale) }\end{array}$ & 3.9 & 30 \\
\hline $\begin{array}{l}\text { The average evaluation of specialists with a higher education in terms of the appro- } \\
\text { priateness of tests in relation to the area of specialisation (5-point scale) }\end{array}$ & 3.4 & 7 \\
\hline $\begin{array}{l}\text { The average evaluation of faculty members in terms of the appropriateness of tests in } \\
\text { relation to the area of specialisation (5-point scale) }\end{array}$ & 3.0 & 9 \\
\hline $\begin{array}{l}\text { The average evaluation of specialists with a higher education with respect to the dif- } \\
\text { ficultness of the test (5-point scale) }\end{array}$ & 4.2 & 6 \\
\hline $\begin{array}{l}\text { The average evaluation of faculty members with respect to the difficultness of the test } \\
\text { (5-point scale) }\end{array}$ & 3.0 & 9 \\
\hline $\begin{array}{l}\text { The average evaluation of bachelor's degree students in terms of the appropriateness } \\
\text { of the study course ( } 5 \text {-point scale) }\end{array}$ & 3.9 & 30 \\
\hline $\begin{array}{l}\text { The average evaluation of specialists with a higher education in terms of the appro- } \\
\text { priateness of the study course ( } 5 \text {-point scale) }\end{array}$ & 4.1 & 7 \\
\hline $\begin{array}{l}\text { The average evaluation of faculty members in terms of the appropriateness of the } \\
\text { study course (5-point scale) }\end{array}$ & 4.9 & 9 \\
\hline
\end{tabular}

Table 4 shows the results of the second segment of research.

The results of student work were average (an average of 5 points according to the RSU study rules. Other forms of examination were sought out to improve the relationship among the selected solution techniques.

\subsection{The Third Segment of the Research}

The third segment of research was conducted during the second half of the first semester of the 2010/2011 academic year. Participants were asked to reject or accept a claim about solution techniques on a five-point scale:

1. very Inappropriate.

2. Inappropriate.

3. Impossible to determine appropriateness.

4. Appropriate.

5. Very appropriate.

Table 5 shows the results of the third segment of the research process. The table does not include evaluations of the content of education, because the results were the same as in the previous segment of research 
Table 5

The results of the third segment of the research

\begin{tabular}{llc}
\hline Names of evaluations & Evaluations & $n$ \\
\hline $\begin{array}{l}\text { The average results of students in tests - the selection of solution techniques in ac- } \\
\text { cordance with the algorithm }\end{array}$ & $67.97 \%$ & 41 \\
$\begin{array}{l}\text { The average evaluation of specialists with a higher education with respect to the dif- } \\
\text { ficultness of the test (5-point scale) }\end{array}$ & 3.6 & 7 \\
$\begin{array}{l}\text { The average evaluation of faculty members with respect to the difficultness of the test } \\
\text { (5-point scale) }\end{array}$ & 5.0 & 9 \\
$\begin{array}{l}\text { The average evaluation of bachelor's degree students in terms of the appropriateness } \\
\text { of the study course (5-point scale) }\end{array}$ & 3.9 & 41 \\
$\begin{array}{l}\text { The average evaluation of specialists with a higher education in terms of the appro- } \\
\text { priateness of the study course (5-point scale) }\end{array}$ & 3.7 & 6 \\
$\begin{array}{l}\text { The average evaluation of faculty members in terms of the appropriateness of the } \\
\text { study course (5-point scale) }\end{array}$ & 3.5 & 12 \\
\hline
\end{tabular}

The results of student work were a bit higher than during the previous segment of the research, but they remained average (an average of five points according to the RSU study rules). The work was continued for that reason.

\subsection{The Fourth Segment of the Research}

The fourth segment of research was implemented during the second semester of the 2010/2011 academic year. Students were assigned individual projects related to data processing - ones that had to be handled with the help of ICT. The results had to be interpreted, too. Traditionally, researchers describe and justify the selected solution technique, record statistical indicators, and interpret them via a text processing application.

For instructors, however, it takes a lot of time to open and analyse each student's file. To make the work easier, the authors recommend the recording of these results in Internet surveys (VisiDati.lv, 2011). Internet surveys make it possible to export the results of student work to a single MS Excel file so that the data can be analysed.

Table 6 shows the results obtained during the fourth segment of the research.

This time students posted fairly good results (6 points in accordance with the RSU study rules). Faculty members rated the appropriateness in relation to the area of specialisation at a level of 4.0 in rounded terms, which means that they think highly of it.

\subsection{An Evaluation of the Knowledge, Skills and Talents of Students in University Informatics Courses}

Faculty members from other higher education institutions have recommended that both tests and independent projects be used in informatics courses, and they agree to the idea that the results can be recorded on the Internet. The authors surveyed the experts to see 
Table 6

The results of the fourth segment of the research

\begin{tabular}{llr}
\hline $\begin{array}{l}\text { Names of evaluations } \\
\text { The average results of students in tests - the selection of solution techniques in ac- } \\
\text { cordance with the algorithm }\end{array}$ & $74.69 \%$ & 56 \\
$\begin{array}{l}\text { Concordance coefficients which describe the appropriateness of the selection of so- } \\
\text { lution techniques }\end{array}$ & 0.277 & 56 \\
$\begin{array}{l}\text { The average evaluation of bachelor's degree students in terms of the appropriateness } \\
\text { of the independent project (5-point scale) }\end{array}$ & 3.7 \\
$\begin{array}{l}\text { The average evaluation of specialists with a higher education in terms of the appro- } \\
\text { priateness of the independent project (5-point scale) }\end{array}$ & 4.3 \\
$\begin{array}{l}\text { The average evaluation of faculty members in terms of the appropriateness of the } \\
\text { independent project (5-point scale) }\end{array}$ & 4.3 \\
\hline
\end{tabular}

what percentage of the final grade should be based on each type of examination. $44 \%$ of the experts $(n=15)$ said that the greatest importance should be given to independent projects. The requirements for such projects are usually similar to those which are related to scholarly research projects among student. If the results of independent projects are recorded on the Internet, then influence should be a bit lower $(38 \%, n=11)$. The experts recommend that the coefficient of influence on the final grade in terms of other types of examinations be the following: $43 \%$ for research done by groups of students, and $13 \%$ for computerised tests.

This means that according to the views of faculty members from other institutions of higher education, test results should have the least effect on the final grade. This supports the thesis of the authors - that students must learn that assignments have various solution techniques and that they must select the most appropriate one of them.

If these coefficients are proportionally recalculated to $100 \%$ and rounded off to numbers which can be divided by 5 , then the final grade should be calculated thus:

If the results of independent projects are recorded via a text processing application, then the percentages are $45 \%$ for independent projects, $45 \%$ for research done by groups of students, and $10 \%$ for examinations. If, however, the results are recorded on the Internet, then the percentages are $40 \%$ for independent projects, $45 \%$ for research done by groups of students, and $15 \%$ for examinations.

The authors believe that methods not involving ICT applications in the examination of knowledge, skills and talents may ensure a more in-depth examination of knowledge, but they take a comparatively large amount of time. A bit less time is required to grade research done by groups of students, because in that case students are divided up into small groups, and it is not necessary to come up with a grade for each description of research or each presentation. In future, there should be more research related to the automation of student examinations and to a more in-depth approach to examining knowledge. 


\section{Conclusions}

1. The authors have managed to conclude that the most appropriate testing form, according to recommendations from faculty members, is a test with several correct answers.

2. Faculty members accept the idea that the results of independent projects can be posted on the Internet.

3. Educational content must be subordinated to the traditional way in which scholarly research projects are organised: finding information, preparing research data for processing, processing of data, processing of texts and presentation of the project.

4. Optimal integration between the MS Excel and SPSS applications must be ensured.

5. In order to improve the relationship between solution techniques, the algorithm for choosing data processing methods should be adjusted:

a) making use of quantitative criteria to examine normal distribution - Kolmogorov-Smirnov, Lilliefors, Shapiro-Wilk;

b) if on the basis of these criteria data are in line with normal distribution, then parametric statistical methods should be used;

c) if there are fewer than five respondents in at least one of the groups in a comparison of two or more independent groups, then correlation analysis must be used in studying the relationships;

d) in order to make sure that students do even better in understanding the relationship among data processing methods, assignments must be classified in the following way: one variable, two variable and three or more variable analysis.

\section{References}

Ārstniecības likums (2011). The Latvian Law on Medicine. http: / /www.likumi.1v/doc.php?id=44108.

Andersone, R. (2007). Izglîtïbas programmu integrācija. (Integration of Education Programmes). In: Materials from an International Scholarly Conference, Society, Integration and Education. Rēzekne University College, 28-34.

Fizisko personu datu aizsardzibas likums (2010). The Latvian Law on the Protection of the Data of Individuals. http: / / www. Iikumi.1v/doc.php?id=4042.

Frolova, L. (1999). Ekonomisko procesu matemātiskā modelēšana. Mathematic Modelling of Economic Processes. Rīga, Turỉba University College of Business, p. 310.

Grūtupa, M., Grope, I., Pavāre, J., KovaI̧ova, Z., Gardovska, D., Rasnačs, O. (2009). CRP, IL 6, PCT un LPB diagnostiskā nozīme sepses att̄̄stības un neitropēnijas ilguma prognozēšanai pacientiem ar I̧aundab̄̄giem audzējiem un febrilu neitropēniju (The Importance of CRP, IL 6, PCT and LPB Diagnosis in Forecasting the Duration of Sepsis and Neutropenia in Patients With Malignant Tumours and Febrile Neutropenia). Zinātniskie raksti (Scholarly Papers), Rīga Stradiņš University, 37-43.

Informācijas atklātības likums (2009). The Latvian Law on Information Openness. http://www.likumi.1v/doc.php?id=50601.

Interaktīvā psiholoğijas enciklopēdija Interactive Encyclopaedia of Psychology (2001). http://www.psihologija.lv.

Jevsjukova, J. (2009). Studentu zināšanu testēšanas vieta augstskolas mācỉbu procesā (The Role of Testing Student Knowledge in the Education Process of Higher Education Institutions). The materials an inter-university 
scholarly, practical and educationally methodological conference, Aspects of Studies and Teaching Under Current Circumstances, 25-29.

www.tsi.1v/Research/Conference/MIP_2009/5.pdf.

The LUIS Register of Courses (2011).

http://luis.lanetlv/pls/pub/kursi.startup?1=2.

Martinsone, K., Karkou, V., Nazarova, N., Vāverniece, I., Rasnačs, O. (2009). Theoretical Bases and Principles of Art Therapy Practice in Latvia, in the UK and in Russia: Findings From a Comparative Study, 7th International Art Therapies - Theory and Practice, Abstracts, Rīga, 25-27.

Pacientu tiesību likums (2009). The Latvian Law on Patient Rights. http: / / www. likumi.1v/dc.php?id=203008.

The Register of Professional Standards (2011).

http://wisc.gov.1v/saturs/profizgl/stand_registrs.shmtl.

Prokofjeva, N. (2007). Datorizētās zināšanu pārbaudes modẹi un metodes (Models and Methods in the Computerised Testing of Knowledge), dissertation. Rìga, RTU.

http://www.3.acadlib.lv/greydoc/Prokofjevas_disertacija/Prokofjeva.pdf.

QuizEgg (2011). Create Online Tests Quickly and Easily.

http: / / www. quizegg.com.

Rasnačs, O., Vītiņš, M. (2011). A data base with ICT learning functions for health care students. The International Journal of Technology, Knowledge and Society, 7(1).

http://ijt.cgpublisher.com/product/pub.42/prod. 739.

Rīga Stradiņš University (2011). http: / /www.rsu. lv/eng.

Rīga Stradinş̌ University (2008). Zinātniskie raksti: internā medicīna, ķirurǵija, medicīnas bāzes zinātnes, stomatoloǵija, farmācija. (Scholarly papers: Internal Medicine, Surgery, Basic Medical Sciences, Dentistry, Pharmaceutics).

Rīga Stradinš̌ University (2009). 2009 gada zinātniskās konferences tēzes. (Theses from the 2009 Scholarly Conference).

Rīga Stradinsš University (2010). 2010 gada zinātniskās konferences tēzes. (Theses from the 2010 Scholarly Conference).

Rīga Stradingš University (2011). 2010 gada zinātniskās konferences tēzes. (Theses from the 2011 Scholarly Conference).

Rīga Stradinš̌ University (2011). Studiju priekšmetu ceI̦veži (Study Guidebooks). http://www.rsu.lv/dokumentu-centrs/category/38-studiju-prieksmetucelvezi.

Skujiņa, V. (2000). Pedagoǵisko terminu skaidrojošā vārdnīca (Explanatory Dictionary of Pedagogical Terminology). Rīga, Zvaigzne ABC.

Teibe, U. (2007). Bioloǵiskā statistika (Biological Statistics). Rīga, University of Latvia.

Teibe, U. (2001). Varbūtību teorijas un matemātiskās statistikas elementi medic̄̄nas studentiem (Elements of Probability Theories and Mathematical Statistics for Medical Students). Rīga, RSU.

The Latvian Law on Statistics (2009).

http: / / www. likumi. Iv/doc.php?id=45932.

VedIa, A. (2000). Uznēmējdarbības kurss (A course on Entrepreneurship). Rīga, Petrovskis \& Co.

VisiDati.lv (2011). http: / /envisidati.lv.

Zakriževska, M., Mihailovs, I.J., Rasnačs, O. (2008). Social Representatives About Politicians: Pilot Research Study. The 4th International Scholarly Conference New Dimensions in the Development of Society, Proceedings, Jelgava, 105-111. 
M. Vīinzš is a professor at the University of Latvia. He is head of chair of lifelong informatics education. His research interests lie in informatics content and methodology at secondary school, and in lifelong education. Results of his research are published in international journals and delivered at international conferences. He is a participant to a intersectorial project of Latvian Science Council, manager and participant to several EUfunded research and development projects. From 1987 to 2008 he was the organizer of Latvian informatics contest, from 1992 to 2008 - of the Latvian national team at world informatics olympiads (IOI). He is a faculty member at the University of Latvia since 1972. During last years he has developed and delivers courses on didactics of school informatics, office and enterprise information systems. He organizes internships, supervises bachelor, master and doctoral works. He performs organizing works. He is a member of several collegial institutions at University and Ministry of Education and Science Level, as well as member of Education Work Group of the Latvian Information and Communications Technology Association - LIKTA.

O. Rasnačs is a lecturer of informatics, mathematics and statistics at the Riga Stradins University, Department of Physics from 1999. He have work expierence from 1996 at the different Latvian high schools. From 2007 he also is PhD student of computer sciences at the Latvia University, Faculty of Computer Science. His research is about apply of ICT, mathematics and statistics in the medicine and social sciences.

\title{
Su specialybe susietų uždavinių ruošimas universitetinio lygio informatikos studiju kursams
}

\author{
Māris VĪTIŅŠ, Oskars RASNAČS
}

Ivairaus amžiaus studentams ir praktikuojantiems specialistams sunku rasti ir nuspręsti kokie duomenu apdorojimo metodai turi būti naudojami siekiant paaiškinti gautus rezultatus tam tikros specializacijos srityje.

Straipsnio autoriai išsiaiškino, kad kai studentai praktiškai nagrinėja užduotis, kurios susijusios su jụ duomenų apdorojimu, tai yra žymiai naudingiau, negu pasiūlytos literatūros naudojimas.

Šiame straipsnyje autoriai nagrinejja tokius klausimus:

(1) Kaip užduotys, kurios duodamos per universitetinio lygio informatikos kursus, gali būti integruojamos su atitinkama specializacijos sritimi naudojant profesinius standartus, vadovus i studijavimą kituose kursuose, kad padètu studentams ir praktikuojantiems specialistais priimti sprendimą apie duomenų apdorojimo metodus, jų naudojimą, ir jų rezultatų interpretacija;

(2) Kaip garantuoti, kad mokomieji duomenys, susieti su specializacijos sritimi, yra gauti statistikos pagrindu mokslo publikacijose?

(3) Kokio turinio medžiaga turi būti pateikiama sveikatos priežiūros ir socialinių mokslų studentams?

(4) Kaip pasirinkti metodus, kurie padètų išspręsti duomenų tvarkymo klausimus?

(5) Kokie yra rekomenduotini principai, kurie padètu įvertinti studentų žinias, igūdžius ir talentus? 